\title{
Reviewed Interpretations and Inspirations on the Development and Strategies of Garden City Theory in Singapore
}

\section{Qinyu Feng*}

The University Of Sheffield, Sheffield S10 2TT, UK

\begin{abstract}
Reconceptualising the construction of Garden Cities in Singapore from the perspective of the history of urban development and urbanization, in conjunction with the development and trends of vertical greening systems. To summarise the principles of development in modern ecosystems in the context of rapid urbanisation and high population density trends: 1. Long-term planning and adherence to ecological principles are required for urban construction and development. 2. Urban development should insist on controlling and guiding the urbanisation process. 3. Strong executive and coordination capacity of the government is an essential force for the development of new cities. 4. The cultivation of urban culture is required to be initiated by the government to promote social consensus and directing the power of the public. 5. Respond to the trend of the times and make flexible use of science and technology (vertical ecosystems) to solve urban problems.
\end{abstract}

Key words: Garden City Ecology City History, Vertical Greening System

Publication date: May, 2021; Publication online: 31 May, 2021

*Corresponding author: Qinyu Feng,

\section{Introduction}

The concept of the garden city comes from the book 'Garden Cities of Tomorrow' by Howard, who is considered to be a pioneer of modern urban planning, a theory that played a major role in $20^{\text {th }}$ century urbanism and spearheaded the construction and development of modern cities (Gatarić et al. 2019, pp. 33-43). However, urbanization is not declining and the proportion of urban areas is expected to reach $66 \%$ by 2050 (UNDESA 2014) (Figure 1).

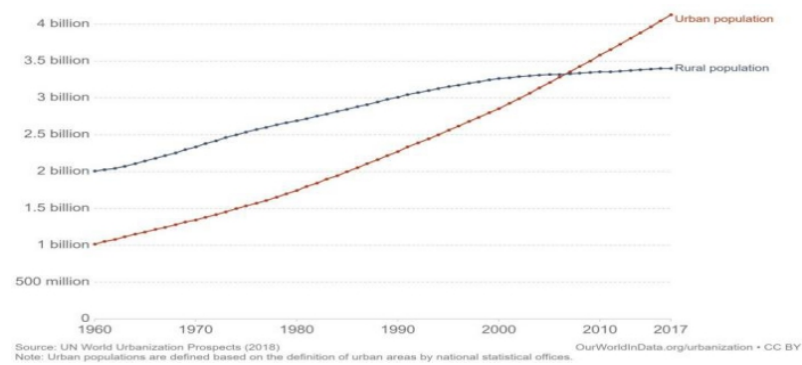

Figure 1. Number of people living in urban and rural areas (UNDESA 2018).

The concept of the garden city comes from the book
'Garden Cities of Tomorrow' by Howard, who is considered to be a pioneer of modern urban planning, a theory that played a major role in 20th century urbanism and spearheaded the construction and development of modern cities (Gatarić et al. 2019, pp. 33-43). However, urbanization is not declining and the proportion of urban areas is expected to reach66\% by 2050 (UNDESA 2014). With the development of technology, urbanization has brought about new urban problems, towering buildings are an inevitable part of future urban development (Ibrahim 2007), and the contradiction between urban construction land and urban greening land is becoming increasingly prominent (Colding 2020), as traditional greening methods are falling below the greening requirements of modern urban development (Russo 2018 , p. 2180). Singapore is acknowledged worldwide for the successful construction of the Garden City, and its famous vertical ecosystem has pointed the way to a new direction for the future of urban development (Abel 2020). Nevertheless, looking at the vast amount of understanding and research on the Singapore Garden City, it is clear that 
the approach to greening and the construction of gardens is not enough. Simple imitation produces useless landscaping, encroaching on the already tight urban land resources and bringing about more urban and social problems.

This paper looks at the history and strategies of garden city development in Singapore, Combining the development of vertical greening systems, and analyses the Singapore garden city model to reconceptualise the experience of building new garden cities.

\section{The Garden City Singapore}

Only Singapore bears any resemblance to the polycentric city Howard planned. With its constellation"of high-density new towns all linked to the main city by a circular metro system, the city- state combines elements of both Howard's and Le Corbusier's visions (Le Corbusier experimented with replacing individual houses with public housing, interpreting Howard's vision in his own way, creating a series of high-rise "vertical garden city" project parks (Bessette 1987).) together in a rare, infrastructure led urban strategy (Liu 1998), that is now the envy of planners around the world (Able 2010).

\subsection{The process of building Garden Cities in Singapore}

\subsubsection{Objective setting for Garden City}

Before 1958, Singapore was a British colony for a long time, and the last version of the master plan before independence was the 1958 master plan. In this plan (Chew 2009), the colonial government explicitly responded to urban development with a decentralization layout, which also included the development of new towns and the use of the Green Belt to limit further growth in the central city (Dale 1999). These measures have similarities to the 1944 Greater London Plan (Abercrombie 1944), and are clearly influenced by Western urban planning theory, which has significant relevance to the Garden City movement advocated by Howard in England.



Figure 2. Professor Otto Koenigsberger, a planner from UN, proposed the concept of Ring City in 1963.

One of the most popular planning schemes was the decentralization pattern - when the central city grew to a certain size, it was surrounded by a number of idyllic cities, forming urban communities, which would allow for more efficient management of the city (Howard 2013). This idea has resulted in a systematic management model in Singapore. In 1959, when Singapore became independent, the massive construction of the city began in earnest. In 1963, Professor Koenigsberger, a United Nations expert on urban development, helped to develop a new version of Singapore's concept plan (Chew 2009). This plan introduced the concept of the 'Ring City' (Abrams and Koenigsberger 1963). The concept planned a city of four million people, with a large natural area at its centre and a series of new towns linked by a ring of traffic on the periphery. This concept provides a fundamental spatial structure for garden city in Singapore (Figure 2).

In the immediate post independence period, the Singaporean nation was in shambles, with the largest urban slums in Southeast Asia and an unemployment rate of $13 \%$ (Schelander 1998). On 15 December 1968, Lee Kuan Yew formally introduced the concept of the "Garden City" to guide and improve the overall habitat of Singapore, which formed the first holistic urban concept to guide the development of Singapore's habitat. This urban concept was a continuation of the "Garden City" movement and was in response to the needs of the Singaporean people (Lin 2010). The concept of the 'ring city', mentioned in 1963, was established in the 1971 plan. Singapore's rapid urbanization was accompanied by the preservation of the natural areas of the city centre (the central catchment and the original forest), a strategy that continues to this day, making it the largest 
ecological core in Singapore today. "The 'ring' also defines a decentralization, ribbon pattern of new towns, a necklace pattern of rings linked by a modern transport system. This structure forms the basis of the Garden City of Singapore (Lin 2010) (Figure 3).

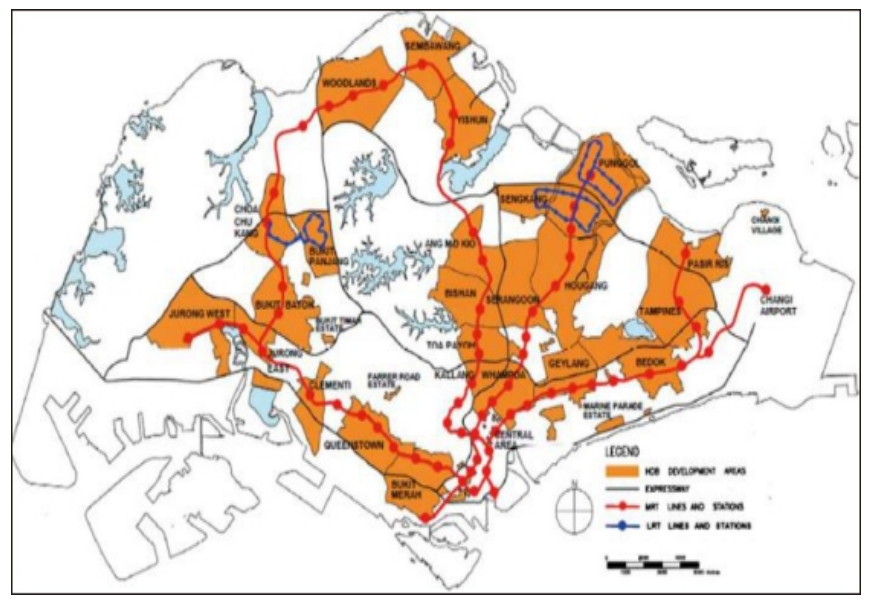

Figure 3. Planning of new towns in Singapore. Uploaded by June Wang.

\subsubsection{Nation-wide green open space construction}

After 1980, open space became the mainstay of the urban design and planning in Singapore as the city grew and urbanites began to emphasise a high quality of life and the need for natural and open public spaces increased. In 1981, the Singapore government proposed a five-year plan to promote five large public parks island-wide. In 1989, the government began to plan for an island-wide green linkage system that would attempt to link all types of open space together through walkways, cycle paths and lanes. In that year, a plan for a network of parks was clearly formulated, specifying six types of open space in Singapore (natural open space, major parks and gardens, sports and open spaces, boundary separations, intrinsic greenways and connectors, and others), with the construction of open space in Singapore thereafter beginning to evolve towards a complete network system.

\subsection{Vertical greening in Singapore}

Anticipating the tension between a rapidly growing population and limited land area, Singapore's new towns take the form of high-rise tenements interspersed with parks, unlike European neighbourhood units. This new format is Singapore's vertical greening system.

\subsubsection{The origin and development of vertical greening}

The origins of the concept of 'vertical greenery' can be traced back to around the 17 th century AD. The labyrinths built by the Greek dynasties of Crete contained mazes that were hedged with greenery to separate spaces, creating an impermeable green wall. After years of exploration, people gradually realized that wall greening could produce better results, so climbing plants were used to decorate the walls and halls of buildings in Eastern Europe, the former Soviet Union and Europe and America. The Patrick Blanc later named this particular form of greenery 'Vertical Gardens', also known as 'Vegetated Living Walls', and 'Living Green' (Blanc 2008).

In recent times, the accumulation of gardening techniques has led to the development of dimensional greening in a more practical direction. In 1959, a 1.2 hectare rooftop garden was built at the Kaiser Center in Oksing, California, USA (Osmundson 1999). Tokyo, Japan, which brought vertical greening into the legal fold in April 1991 and issued an urban greening law (Chang 2010). The Polish government has made Warsaw the world's greenest capital after decades of greening, with 78 square metres of green space per person (Szymańska 2015). In Germany, the "Green House Project" has commercialized the components needed to build walls, and $80 \%$ of German roofs are now green (Doroshenko 2018). Brazil has developed a 'bio-wall', which is a wall made of hollow bricks and filled with resin, grass and fertilizer for vertical greening (Huaqing 2015). the garden city of Singapore has buildings, street sides, roofs, balconies and walls covered in green everywhere (Beatley 2012). Germany, Japan and South Korea and other countries of vertical greening related technology has been quite mature.

The development of vertical greening has developed globally, diversified and intensified. As an urban greening method that integrates ecological, economic and aesthetic benefits, vertical greening has been strongly promoted by countries such as the United States, Germany, Japan and Singapore (Perini and Rosasco 2013). First of all, vertical greening can effectively alleviate the contradiction between greening and building land, and break away from the limitations of traditional greening in terms of the number of plants and planting area, creating the greatest greening effect with the smallest footprint, finding a breakthrough for increasing the greening rate of the city, and also finding a new direction for urban land resource planning (Pérez-Urrestarazu 2015). Secondly, vertical greening can 
improve the urban heat island effect, beautify the environment, effectively reduce the urban drainage load, avoid urban water logging, absorb dust and reduce noise, and be ecologically friendly (Price and Jefferson 2015). In addition, from the overall perspective, vertical green walls have a high initial investment cost, but a low maintenance cost later on. The special planting process ensures that the plants are evergreen throughout the seasons, saving the cost of planting, achieving automatic drip irrigation and fertilization, saving water resources and reducing manual maintenance costs (Perini and Rosasco 2013).

The "vertical greening system" has created the "Garden of Singapore", and it can also be said that Singapore's garden ecology philosophy has created the unique "vertical green garden" appearance of Singapore. Singapore has spent 53 years creating a "garden city" that incorporates greenery into the urban fabric.

\subsubsection{Skyrise greenery in Singapore}

In Singapore, the combining of vertical greening systems with skyscrapers has given rise to sky gardens and high-rise greenery that help reduce the heat island effect in the city and fill in the pristine greenery encroached upon by buildings.

Pictured below is the Sky Park on the roof of Marina Bay Sands Hotel, which overlooks the Singapore skyline. At 200 metres above ground level, Sky Park is larger than three football pitches and comes complete with viewing decks, over 250 trees and a 150-metre infinity pool (Figure 4).

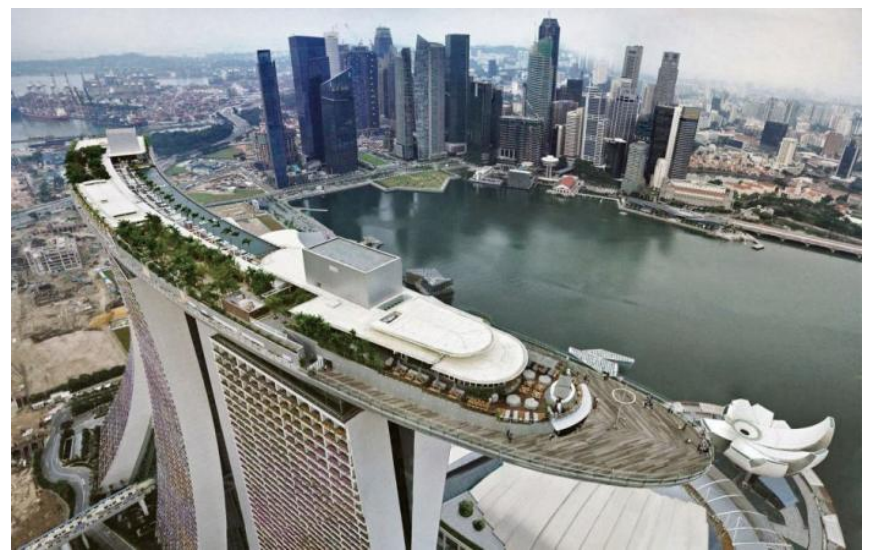

Figure 4. Marina Bay Sands Integrated Resort Skypark ${ }^{\circledR}$

Parkroyal Singapore claims to have a total leafy green cover of over $200 \%$ of the total floor area and uses vertical greenery to replace the original greenery lost when the hotel was built. The 12-storey tower features a curved solar-powered sky garden overlooking the city park in the Central Business District (Figure 5).



Figure 5. Hotel Review: Parkroyal Collection Pickering, Singapore.

\subsubsection{Vertical gardens in Singapore}

The impressive 'Gardens by the Bay' development is an integral part of an ambitious strategy by the government to transform Singapore from a 'Garden City' into a 'City in a Garden' (Han 2017).

The Bay Gardens, a popular retreat for many local residents, features 'super trees' that use technology that mimics the ecological functions of trees. The solar-powered photovoltaic cells on these Super Trees have various practical functions, including lighting and rainwater harvesting for irrigation and fountain displays. The Super Trees also provide some of the intake and exhaust functions of the greenhouse cooling system (Figure 6). These unusual vertical gardens perform a multitude of useful and aesthetic functions, such as providing shade and working as environmental engines for the gardens.



Figure 6. Supertrees, Gardens by the Bay, Singapore.

The 2,289 square metre Treehouse Apartments on Chestnut Avenue in Singapore has become the world's largest vertical garden. Standing 24 storeys high, this green wall is expected to save the building over $\$ 500,000$ in energy and water costs annually (Figure 7). 




Figure 7. The world's largest vertical garden - Tree House condominium, Singapore

\subsubsection{Vertical communities in Singapore}

The Kampung Admiralty is the first public building complex in Singapore to combine all public facilities and service spaces into a single building volume (Figure 8).

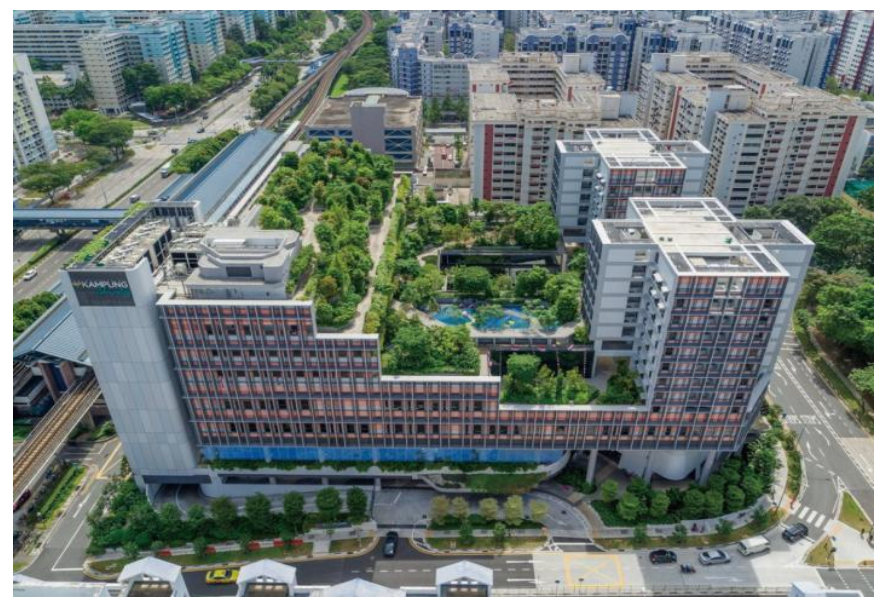

Figure 8. Kampung Admiralty aerial view of west elevation $\bigcirc k$. Kopter

\subsubsection{Vertical Greenery Policy in Singapore}

With the progress of urbanisation, more cities are affected by the current situation of more population and less land, and tall buildings are the inevitable condition of future urban development. The traditional greening methods are far from meeting the greening needs of modern urban development. Environmental problems such as atmospheric pollution, noise pollution, heat island corresponding, greenhouse effect have become the main factors restricting the healthy development of urban ecology, which makes vertical greening an inevitable choice for future urban development.

The Singapore government has encouraged the widespread use of new technologies to address the conflict between scarce land resources and the growing demand for public green space with vertical greening systems, and has collaborated with designers from around the world to create a stunning array of architectural and landscape works.

\subsection{The leading role of the Singapore government}

\subsubsection{Control of the urbanisation process and public housing policy}

Singapore's Garden City has been built on the strength of the government. The government has progressively and rationally controlled urbanization through policies to build public housing in the city. During the rapid urbanization stage, such a policy avoided the massive acquisition of land by bloated capitalists, which inflated the cost of housing and encroached on the public interest, and preserved and built a large number of public green zones. The Singaporean government has guided urbanization through public housing construction in such a way as to keep the scale of each new city within a limited space without overspreading, thus achieving the 'new city model'. Furthermore, the Singapore government has established a number of regulatory bodies. These governing bodies have played an important role in promoting the development of the Garden City.

\subsubsection{Garden City Action Committee}

In 1973, the Garden City Action Committee (GCAC) was set up and headed by the top state employee, comprising the Ministry of National Development (Tan 2006), the Jurong New Town Corporation and the Housing and Development Board, as an overarching The GCAC is a coordinating body. This organization not only coordinates different government agencies and oversees land use planning, but also provides planning standards for open space and park development. The National Parks Board and the Department of Development, the Housing Authority and the Urban Development Authority have all played a key role in the development of the Garden City (Ooi 2005).

\subsubsection{The development of urban culture}

Therefore, the success of Singapore rested on the cultivation of an urban culture of the " Garden City ". This culture became the core of Singapore's national identity and national culture. It is because the conceptual objectives of 
Singapore's Garden City are for the betterment of the nation's citizens, to have ensured the basic interests of its citizens and to have limited the encroachment of capital and inequality that this culture has been able to reach the hearts and minds of the people. The 'Garden City' concept was initiated from the top down by the government and gradually transformed into a bottom up public effort, with the nation working together to promote the development of the 'Garden City'.

\section{Conclusion}

The success of Singapore in the Garden City is both an inheritance and development of the spirit of Howard's Garden City, and a new direction for future urban development. However, simply imitating the vertical greening model of Singapore is meaningless, as it takes up huge amounts of public space, causes land prices to rise and brings about more urban problems. Therefore, it is worthwhile to review and learn from the strategies of Singapore for urban development and planning.

Firstly, urban construction and development should maintain ecological principles and ensure a minimum area of public greenery. In addition, the government should take the lead in the urbanisation process, control the involvement of capital, keep housing prices stable and protect the quality of life of the citizens, in order to achieve universal participation. Finally, technology should be used wisely and boldly to solve urban problems. Vertical ecosystems are embedded throughout Singapore, influencing all aspects of urban development. These technologies have enhanced the quality of life of people.

\section{Disclosure statement}

The author declares no conflict of interest.

\section{References}

[1] Abel, C. (2010). The vertical garden city: towards a new urban topology. CTBUH journal, 2(1), 20-30.

[2] Abercrombie, P. (1944). Greater London Plan. HM Stationery Office. Anon, 2002. Half the world will go urban in five years. (World Urbanization Prospects: The 2001 Revision). UN Chronicle, 39(3), p.36.

[3] Abrams, C., Kobe, S., \& Koenigsberger, O. (1963). Growth and urban renewal in Singapore (pp. 63-84). Retrieved August 1, 2014, from MIT Students' Portal website:

http://stuff.mit.edu/afs/athena/ course/11/11.337/www/MIT_Workshop_Material/MIT_Wor kshop

Material/readings/abrams\%20kobe\%20koenigsberger_singa pore_1963.pdf; The Straits Times, 23 Mar 1970, p. 8.

[4] Beatley, T. (2012). Singapore: How to grow a high-rise city in a garden. SiteLINES: A Journal of Place, 8(1), 14-17.

[5] Besset, M., \& Corbusier, L. (1987). Le Corbusier/to Live With the Light. Rizzoli International Publications.

[6] Blanc, P. (2008). The vertical garden: From nature to the city. WW Norton \& Company.

[7] Colding, J., Gren, Å., \& Barthel, S. (2020). The Incremental Demise of Urban Green Spaces. Land, 9(5), 162.

[8] Chang, K. F., \& Chou, P. C. (2010). Measuring the influence of the greening design of the building environment on the urban real estate market in Taiwan. Building and Environment, 45(10), 2057-2067.

[9] Chew, V. (2009). History of urban planning in Singapore. National Library Board. Retrieved July 23, 2016 from http:/eresources. nlb. gov. sg/infopedia/articles/SIP_1564_2009-09-08. html.

[10] Doroshenko, V. (2018). THEORETICAL AND METHODICAL APPROACHES TO DETERMINATION OF CONCEPT" GREEN BUILDING". THE ACTUAL PROBLEMS OF REGIONAL ECONOMY DEVELOPMENT, 2(14), 31-38.

[11] Dale, O. J. (1999). Urban planning in Singapore: The transformation of a city. Oxford University Press, USA.

[12] Gatarić, Dragica et al., 2019. The origin and development of Garden cities: An overview. Zbornik radova (Univerzitet u Beogradu. Geografski fakultet), 2019(67-1), pp.33-43.

[13] Huaqing, M. A. (2015). Application and Development of Vertical Greening in Urban Landscaping. Journal of Landscape Research, 7(1), 41.

[14] Howard, E. (2013). Garden cities of to-morrow. Routledge.

[15] Han, H. (2017). Singapore, a garden city: Authoritarian environmentalism in a developmental state. The Journal of Environment \& Development, 26(1), 3-24.

[16] Ibrahim, E. (2007). High-Rise Buildings-Needs \& Impacts. In CIB World Building Congress (Vol. 2007).

[17] Lin, Y. U. A. N. (2010). Renewed Interpretation and Inspirations of the Singapore Garden City under the Context of City History. Landscape Architecture, 6. 
[18] Manso, M., \& Castro-Gomes, J. (2015). Green wall systems: A review of their characteristics. Renewable and sustainable energy reviews, 41, 863-871.

[19] Ooi, G. L. (2005). Sustainability and cities: concept and assessment. World Scientific.

[20] Osmundson, T. (1999). Roof gardens: history, design, and construction. WW Norton \& Company.

[21] Pérez-Urrestarazu, L., Fernández-Cañero, R., Franco-Salas, A., \& Egea,

[22] G. (2015). Vertical greening systems and sustainable cities. Journal of Urban Technology, 22(4), 65-85.

[23] Price, A., Jones, E. C., \& Jefferson, F. (2015). Vertical greenery systems as a strategy in urban heat island mitigation. Water, Air, \& Soil Pollution, 226(8), 247.

[24] Perini, K., \& Rosasco, P. (2013). Cost-benefit analysis for green façades and living wall systems. Building and
Environment, 70, 110- 121.

[25] Russo, Alessio \& Cirella, Giuseppe, 2018. Modern Compact Cities: How Much Greenery Do We Need? International journal of environmental research and public health, 15(10), p.2180.

[26] Szymańska, D., Lewandowska, A., \& Rogatka, K. (2015). Temporal trend of green areas in Poland between 2004 and 2012. Urban Forestry \& Urban Greening, 14(4), 1009-1016.

[27] Schelander, B. (1998). Singapore: A History of the Lion City. Center for Southeast Asian Studies with the School of Hawaiian, Asian, and Pacific Sudies at the University of Hawaii at Manoa.

[28] Tan, K. W. (2006). A greenway network for Singapore. Landscape and urban planning, 76(1-4), 45-66. 